vessels and of bodies such as pendulums, when totally immersed in fluid, are also adverted to.

Twenty-five useful maps and charts are attached showing the general progress of the survey, particularly on the coasts of Florida, California, Oregon, and Carolina; together with illustrations of the apparatus used. As compared for instance with the precise drawings given by General Ibanez in his Reports in 1860 and $186_{5}$ on the Madrid base-line, there may perhaps be room for improvement in the finish of the illustrations given in this Report.

In the Report of the Superintendent for I 883 we shall look forward with interest to the results of the experimental researches on the force of gravity, by Assistant C. S. Peirce, who is now visiting Europe for the purpose of his inquiries.

In the success with which the Superintendent has been able to deal with the different brancbes of his department, much is due, as he indicates, to the forethought and systematic treatment of his eminent predecessors, particularly to Cariile P. Patterson, to whose memory a graceful tribute is rendered in the Report; as well as to the able assistance which the Government have placed at the Superintendent's disposal.

\section{AGRICULTURE IN SUSSEX 1}

$\mathrm{T}^{\mathrm{H}}$ IS Report bears evidence of a considerable amount of careful research bearing upon the agricultural practice of Sussex. The honorary secretary, Major Warden Sergison, must be congratulated upon his zealous administration of the finances, whereby an annual income of about $770 l$. has been secured for the three successive years of active operations. This Report deals with the results of the third year's work, which completed the period over which it was originally calculated that the work should be extended. We are therefore in a position to form some opinion as to the practical value of the results which have been gained. It appears from this Report that it is intended to extend this inquiry.

These experimental researches have been conducted by Mr. Thomas Jamieson, the Fordyce Lecturer on Agriculture in the University of Aberdeen, and it will be interesting to notice the improvements and economies which are claimed in his Report as resulting from this rather costly investigation. He says:-_"The results are too numerous to give, ..." but "an attempt will be made to give in a general way the lessons they seem to teach." $\mathrm{He}$ then proceeds to indicate these, placing them in the form of question and answer. We will take the first of these.

"What food do plants need? Prior to the experiments now recorded, the answer to this question would have been 'Nitrogen, phosphorus, potassium, sulphur, calcium, magnesium, iron.' The results of the experiments warrant us in saying that the latter four substances may be disregarded by farmers. We thus realise the value of experiments. If the farmer of ioo acres will lay his manure bill before a chemist, and ask him to calculate how much he has paid for those useless-or hurtful-ingredients, he will recognise the direct benefit of such experiments."

Those who have watched the good work which $\mathrm{Mr}$. Jamieson has done in connection with the Aberdeenshire Agricultural Association, and who have recognised the opposition with which he had to contend, cannot but regret the hasty conclusion at which he has arrived. It is a very bold assertion to make that sulphur, calcium, magnesium, and iron are not needed as plant-food. He cautions his friends "not to be led away by opposed statements, however plausible, if unaccompanied by proof." In this case Mr. Jamieson shall supply his own proof, for which purpose we refer to the Report of the

1 "The Annual Report of the Proceedings of the Sussex Association for he Improvement of Agriculture in Sussex. Season $188{ }_{3}$."
Aberdeenshire Agricultural Association, 1875-76, p. 29. Here Mr. Jamieson reports a very valuable series of experiments which he made. White sand was supplied with a!l the ingredients found in turnips-except one-and turnip seeds were then sown. He says:- "Precisely the same sand, precisely the same seed, precisely the same watering, precisely the same ingredients added, except onewhich was purposely omitted-calcium. In consequence of this omission, although all the other ingredients were present in abundance, the healthy seed produced healthy young plants, but speedily the whole of them died. Just as in an ordinary chemical experiment the desired substance' cannot be formed if one of the essential ingredients is absent." The lesson derived from this experiment is perfectly consistent with agricultural science, and it is a source of profound surprise to find that this substance-calcium-is one of the four bodies named in the Sussex Report as being unnecessary, and that it should be stated that "farmers will not hurt their crops by omitting these four elements." This is a dangerous lesson to deduce from this valuable series of experiments, and we regard it with the greater regret because the facts do not justify such a conclusion.

Other examples might be selected from this Report, which conflict with other experimental trials conducted with, at least, equal care, which also tend to show the necessity for taking more practical views of the results gained. The opinions expressed upon permanent pasture are also open to severe criticism. If the general series of Sussex experiments be placed in comparison with the investigations carried out for the Aberdeenshire Agricultural Association, they will be found devoid of those great national advantages which must long attach to the Scotch experiments. The value of the Aberdeen Association work has never been as fully appreciated as it deserves, and the agricultural public would have been highly gratified if the Sussex Association experiments had been equally definite and satisfactory.

\section{SOCOTRA}

FOUR years have elapsed since an expedition was sent out from this country by the British Association and the Royal Society to explore the Island of Socotra. With the exception of diplomatic visits by the resident at Aden in the two or three preceding years, and of a short exploration in 1847 by the French.naturalist Boivin, there is no record of any European having sojourned on the island since the date, forty years ago, of its abandonment by the Indian troops which had occupied it for this country during four years, and Wellsted's account of his survey of the island (in Fourn. Roy. Geog. Sor. v. 1835) made in 1834 , has been up till now the most recent and most satisfactory. It is remarkable that an island so long neglected and forgotten should be visited in two successive years by exploring expeditions; yet this has happened. In I 88I a party of German explorers followed the British Expedition. This German Expedition to Socotra formed part of a scheme of scientific exploration of many unknown or but little-known regions of the globe set on foot by Dr. Emil Riebeck, and for which his liberality provided the means, and the results of this portion of his undertaking, some account of which now lies before us, must be gratifying to him as they are valuable to and welcomed by science. Dr. Riebeck was accompanied to Socotra by the well-known traveller Dr. Schweinfurth and two other companions, Drs. Mantay and Rosset-a quartet of observers well qualified to take advantage of every opportunity of extending our knowledge of nature. Many

I “ Ein Besuch auf Socotra mit der Riebeck'schen Expedition." Vortrag von Professor Dr. Schweinfurth. (Freiburg, r 884 .)

"Allgemeine Betractungen über die Flora von Sc cotra," von G. Schweinfurth. Sep. Abd. aus Engler's botrnischen Jahrbiuchern, v. (1883).

furth. Sep. Abd. aus Engler's botanischen Jakrbiüchern, v. (1883). d. deutsch. Malakol. Gesellschaft, No. 10(188I). 